\title{
Prognostic value of sialyl-Tn antigen in gastric carcinoma
}

\section{ORIGINAL ARTICLE Annals of Cancer Research and Therapy}

\section{Kiyoshi Maeda $\cdot$ Yong-Suk Chung $\cdot$ Yasuyuki Kato $\cdot$ Naoyoshi Onoda $\cdot$ Atsunori Nitta $\cdot$ \\ Yasuyuki Kondo - Yuichi Arimoto - Yosito Yamashita - Michio Sowa*}

\begin{abstract}
Sialyl-TN antigen (STN ; NeuAc $2 \rightarrow 6 \mathrm{GalNac} a 1-0-\mathrm{Ser} / \mathrm{Thr}$ ) is a mucin-associated antigen expressed by some neoplasms. In this study, STN expression was investigated immunohistochemically in 152 patients with gastric cancer who underwent curative surgical resection. STN expression was detected in 74 of the tumors (48.7\%). There was no significant relationship between STN positivity and histologic type. However, STN positivity was significantly higher in patients with lymph node metastasis than that in those without metastasis $(P<0.01)$. In addition, STN positivity increased as tumor invasion became deeper and the STN-positive rate also became higher as the histologic stage increased.

Furthermore, patients with STN-positive tumors had a significantly poorer prognosis than those with STNnegative tumors $(p<0.01)$.

Our findings suggest that STN expression is related to the depth of invasion, lymph node metastasis, and stage of gastric carcinoma and that it may be a useful prognostic factor.

Ann Cancer Res Ther 2 (2) : 205-208, 1993 / Received 9 Jul 1993

Key words : sialyl-Tn antigen, gastric carcinoma, immunohistochemical study, prognostic factor
\end{abstract}

Glycosialic antigens have attained an important role as tumor markers in recent years, and one such antigen is the sialyl-Tn antigen $(\mathrm{STN})^{1 \sim 33}$. This is a disaccharide with an 0 -glycosidic linkage to the apomucin polypeptide (NeuAc $\alpha 2 \rightarrow 6$ GalNac $\alpha$ 1-0$\mathrm{Ser} / \mathrm{Thr}$ ), and thus is markedly different from conventional tumor markers such as sialyl Lewis-a $(\text { CA 19-9) })^{4}$, sialyl Lewis ${ }^{x}-1(S L X)^{5)}$ and SPan-1 antigen ${ }^{\circ}$.

A monoclonal antibody (TKH2), that recognizes STN was recently generated using bovine submaxillary mucin as the immunogen, and immunohistochemical studies have demonstrated its reactivity with a large number of adenocarcinomas ${ }^{7-16)}$. In addition, Itzkowitz et al. ${ }^{n}$ have reported that patients with STN-positive colon cancer have a poor prognosis.

In the present study, we investigated the relationship between STN expression and the prognosis of gastric cancer, by performing an immunohistochemical study using the TKH 2 monoclonal antibody.

\section{Materials and methods}

\section{Clinical materials}

A total of 152 patients with gastric carcinoma who underwent curative resection at our hospital were studied. They included 110 males and 42 females, aged from 33 to 83 years, with an average age of 58.2 years. These patients were pathologically staged according to

\footnotetext{
* First Department of Surgery, Osaka City University Medical School
}

the Japanese general rules for gastric cancer study ${ }^{17}$. Histologically, 80 patients had stage I disease, 21 had stage II disease, 41 had stage III disease, and 10 had stage IV disease. All of the patients were followed up for at least 5 years.

Resected tumor specimens were fixed in $10 \%$ formalin and embedded in paraffin, after which $5 \mu \mathrm{m}$ sections were cut for immunohistochemical staining.

\section{Immunohistochemical staining}

The tissue localization of STN was determined immunohistochemically using the streptoavidin-biotin method. All procedures were conducted at room temperature. The tissue sections were deparaffinized in xylene, dehydrated in ethanol, and incubated with $0.3 \%$ hydrogen peroxidase in methanol for $30 \mathrm{~min}$ to block endogenous peroxidase activity. Then the slides were washed three times in $0.01 \mathrm{M}$ phosphate-buffered saline (PBS) and were treated with 5\% normal rabbit serum for $20 \mathrm{~min}$ to reduce nonspecific antibody binding. The TKH2 monoclonal antibody recognizing STN antigen (Otsuka Assay Lab. Ltd.) was diluted 20-fold and reacted with the sections for one hour. After further washing with PBS, the biotin-labeled secondary antibody (polyclonal rabbit anti-mouse IgG+IgM+IgA ; Vector Lab., Burlingame, CA) was added for $30 \mathrm{~min}$, followed by three washes with PBS. Next the slides were incubated with the avidin-biotin-peroxidase reagent (Vector $L a b$.) for $30 \mathrm{~min}$.

Finally, the slides were reacted with diaminobenzidine substrate for $5 \mathrm{~min}$, counterstained with methyl green, 


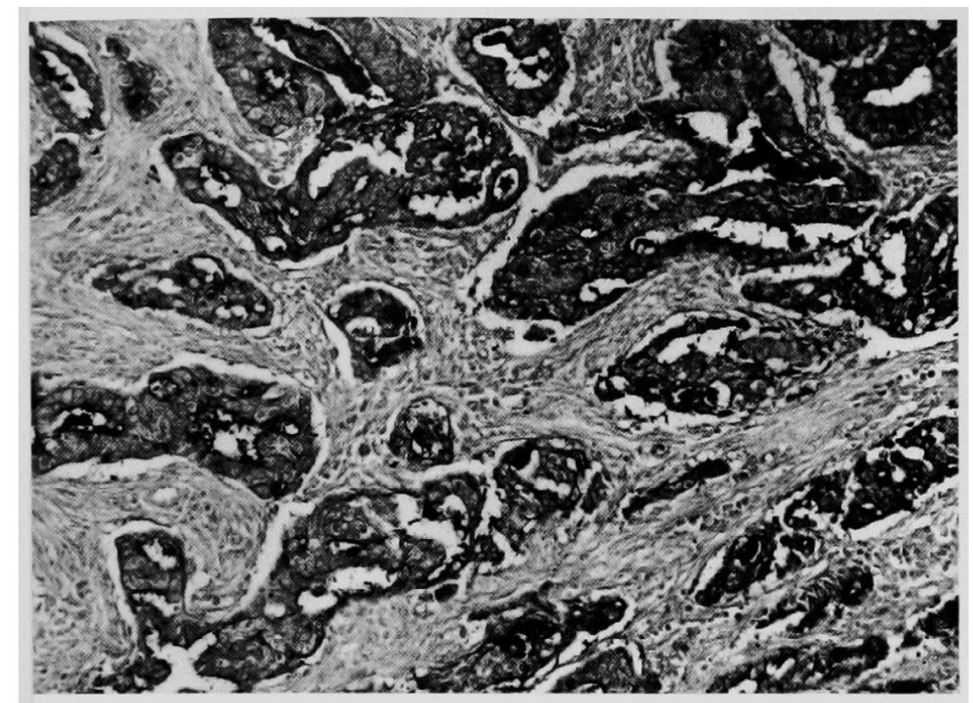

Fig.1 Immunohistochemical staining of STN with monoclonal TKH2 antibody.

Expression of STN was observed in the cytoplasm or the apical portions of tumor cells. $(\times 200)$

and mounted. Negative controls were incubated with normal mouse serum in place of the primary antibody.

\begin{tabular}{|c|c|c|}
\hline & \multicolumn{2}{|c|}{ Number of patients (\%) } \\
\hline & STN positive $(n=74)$ & STN negative $(n=78)$ \\
\hline age (mean $\pm S D$ ) & $57.5 \pm 12.4$ & $58.2 \pm 11.6$ \\
\hline \multicolumn{3}{|l|}{$\operatorname{sex}$} \\
\hline $\int$ male & $53(71.6)$ & $57(73.1)$ \\
\hline female & $21(28.4)$ & $21(26.9)$ \\
\hline \multicolumn{3}{|l|}{ histologic type } \\
\hline $\int$ well $\left.* 1\right)$ & $29(39.2)$ & $44(65.4)$ \\
\hline$\{$ poorly*2) & $45(60.8)$ & $34(34.6)$ \\
\hline \multicolumn{3}{|l|}{ stage } \\
\hline $\int \mathrm{I}$ & $28(37.8)$ & $52(66.7)$ \\
\hline II & $11(14.9)$ & $10(12.8)$ \\
\hline III & $28(37.8)$ & $13(16.7)$ \\
\hline IV & $7(9.5)$ & $3(3.8)$ \\
\hline
\end{tabular}

*1) well differentiated adenocarcinoma

*2) poorly differentiated adenocarcinoma

Slides were assessed for STN expression by a pathologist who was blined to the clinicopathologic data, and a tumor was considered positive for the antigen, if its was detected in more than $5 \%$ of the cells in all the fields examined.

\section{Statistical analysis}

For statistical analysis, the chi-squared test was employed. Survival curves were calculated by KaplanMeier method and analyzed by the generalized Wilcoxon test. A significant difference was defined as present at $\mathrm{p}<0.05$.
Table 2 Relationship between clinicopathologic factors and the expression of STN

\begin{tabular}{|c|c|}
\hline & $\begin{array}{l}\text { Number of patients } \\
\text { STN positive (\%) }\end{array}$ \\
\hline \multicolumn{2}{|l|}{ Histologic type } \\
\hline well $^{\text {a) }}(n=72)$ & $29(40.3)$ \\
\hline$p_{\left.00 r^{b}\right)}(n=80)$ & $45(56.3)$ \\
\hline \multicolumn{2}{|c|}{ Lymph node metastasis } \\
\hline negative $(n=91)$ & $33(36.3)$ \\
\hline positive $(n=61)$ & $41(67.2)^{* 1)}$ \\
\hline \multicolumn{2}{|l|}{ Depth of invasion } \\
\hline$m(n=30)$ & $10(33.3)$ \\
\hline $\operatorname{sm}(n=48)$ & $24(50.0)$ \\
\hline $\operatorname{pm}(n=25)$ & $10(40.0)$ \\
\hline ss $(n=10)$ & $4(40.0)$ \\
\hline se-sei $(n=39)$ & $26(66.7)^{* 2)}$ \\
\hline \multicolumn{2}{|l|}{ Stage } \\
\hline$I(n=80)$ & $28(35.0)$ \\
\hline II $(n=21)$ & $11(52.4)$ \\
\hline III $(n=41)$ & $28(68.3)^{* 3)}$ \\
\hline IV $(n=10)$ & $7(70.0)$ \\
\hline
\end{tabular}

a): well differentiated adenocarcinoma

b) : poorly differentiated adenocarcinoma

*1) : significantly higher than in patients without lymph node metastasis ( $<<0.01$ )

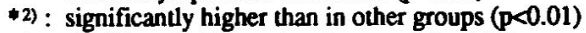

*3): significantly higher than in stage I ( $p<0.05)$

\section{Results}

Normal gastric mucosa was not stained by TKH2. Typical examples of STN-positive tumor cells are illustrated in Fig.1. STN was mainly distributed in the cytoplasm or the apical portions of the carcinoma cells. STN expression was detected in $74(48.7 \%)$ tumors. Table 1 summarizes the clinical data on the 152 patients in relation to the expression of STN by their tumors. There were no significant differences between the patients with STN-positive tumors and those with STNnegative tumors, although advanced cancers were more common in the STN-positive patients.

The relationship between STN expression and various clinicopathologic factors is shown in Table 2. There was no significant association between STN expression and the histologic type of the tumor. However, significant differences were noted with respect to depth of invasion, lymph node metastasis, and histologic stage.

The STN-positive rate was significantly $(p<0.01)$ higher in patients with lymph node metastasis than that in those without metastasis. In patients with serosal infiltration (se or sei), STN positivity was significantly more common $(p<0.01)$ than in those without serosal invasion ( $\mathrm{m}, \mathrm{sm}, \mathrm{pm}$, and $\mathrm{ss})$. There was also a tendency for the STN-positive rate to increase as the histologic stage increased, and positivity for STN was 

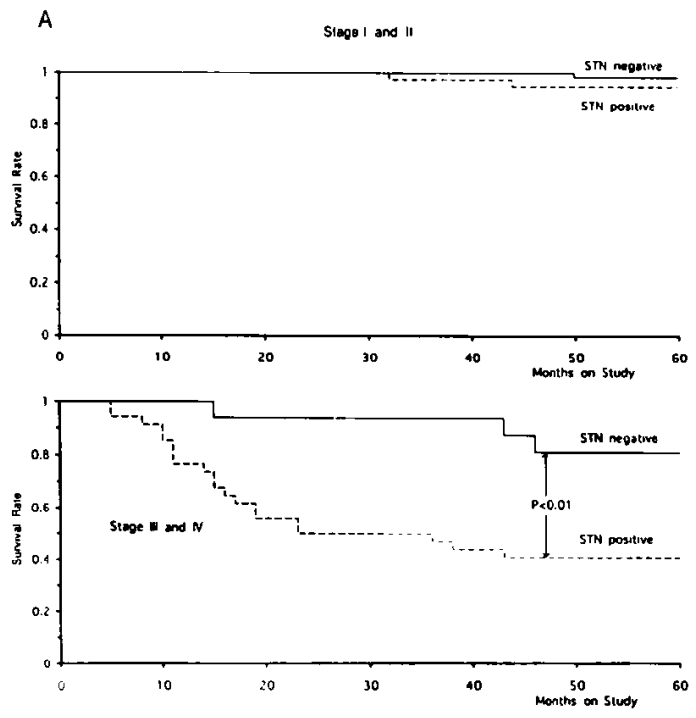

Fig.2 Survival rates after curative resection

A : Patients with stage I and II disease

B : Patients with stage III and IV disease

significantly more common $(p<0.05)$ in stage II compared with stage I.

Among the 152 patients, 26 developed tumor recurrence and 4 died of another disease after surgery. These 4 cases were excluded from assessment of the prognosis.

The recurrence rate in patients with STN negative tumors was $5.3 \%$ (4/75), whereas it was $30.1 \%$ (22/73) for patients with STN-positive tumors which was significantly higher $(p<0.01)$ than in the former group. Survival of the 148 patients was calculated according to stage using Kaplan-Meier method. As shown in Fig.2, there was no significant difference in outcome between the STN-positive and STN-negative groups in stages I and II. On the other hand, a significant difference was observed between these two groups and prognosis of patients with STN-positive tumors was significantly worse $(p<0.01)$ in stages III andIV .

\section{Discussion}

STN is a mucin-associated carbohydrate antigen expressed by a variety of adenocarcinomas ${ }^{7 \sim 16}$. This antigen is considered to be part of the core region of mucin oligosaccharides, and thus differs considerably from type 1 chain carbohydrate antigens, like CA19-94) and type 2 chain antigens, like SLX ${ }^{5}$. Thus, it is assumed that the features of STN as a tumor marker will also differ from those of other antigens.

The present study showed that STN expression was higher in patients with lymph node metastasis and histologically advanced disease. In addition as tumor invasion became deeper, the STN-positive rate became higher. Moreover, as STN-positive tumor cells increased in frequency, the histologic stage became more advanced. Watanabe et al. ${ }^{(8)}$ studied serum STN levels in gastric cancer patients and reported that the mean STN level and the positivity rate both increased with advancing tumor stage and degree of lymph node metastasis. Our results also suggested that the detection of STN expression may be useful for predicting the clinical stage.

In relation to prognosis, Itzkowitz et al. ${ }^{7}$ performed an immunohistochemical study of colon cancer and reported that the prognosis was poorer in patients with STN-positive tumors than in those with STN-negative tumors. Our study, also, showed a significantly worse survival in the STN-positive group, and the expression of STN appears to be a useful prognostic factor in gastric carcinoma, especially in patients with advanced disease. Thus, STN may prove useful in the selection of patients for postoperative adjuvant treatment such as chemotherapy or immunotherapy.

Ogata et al. ${ }^{199}$ recently reported that STN antigen can interfere with natural killer cell cytotoxicity and thus may allow cancer cells to escape detection or killing by the immune system. The reason why STN positivity was related to a poor prognosis is still unknown, but we suggest that some such immune escape mechanism may influence the prognosis of patients with STN-positive tumors.

In conclusion, this retrospective study demonstrated that detection of STN expression is useful for the prediction of tumor stage and may be a good prognostic indicator in patients with gastric cancer.

\section{References}

1) Hakomori S, Kannagi R : Glycosphingolipids as tumor-associated and differentiation markers. J Natl Cancer Inst, 71 : 231-235, 1983.

2) Kieldsen $T$, Clausen $H$, Hirohashi $S$, Ogawa $T$, lijima $H$, Hakomori $S$ : Preparation and characterization of monoclonal antibodies directed to the tumor-associated o-linked sialosyl 2 $\rightarrow$ 6-N-acetyl galactosaminyl (sialosyl-Tn) epitope. Cancer Res, $48: 2214-2220,1988$

3) Dahiya R, Itzkowitz SH, Byrd JC, Kim YS : Mucin oligosaccharide biosynthesis in human colonic cancerous tissues and cell lines. Cancer, $70: 1467-1476,1992$.

4) Koprowski H, Herlyn M, Steplewski Z. Specific antigen in senum of patients with colon carcinomas. Science, $212: 53-55,1981$.

5) Iwanari O. Miyako J, Date Y. : Differential diagnosis of ovarian cancer, benign ovarian tumors and endometriosis by a combination assay of serum sialyl SSEA-1 antigen and CA 125 levels. Gynecol Obstet Invest, $29: 71-74,1990$

6) Chung YS, Ho JJ, Kim YS, Tanaka H, Nakata B, Hiura A, Motoyoshi $\mathrm{H}$, Satake $\mathrm{K}$, Umeyama $\mathrm{K}$ : The detection of human pancreatic cancer-associated antigen in serum of cancer patients. Cancer, $69:$ 2368-2378, 1992.

7) Itzkowitz SH, Bloom EJ, Kokal WA, Modin G, Hakomori S, Kim YS : A novel mucin antigen associated with prognosis in colorectal cancer patients. Cancer, $66: 1960-1966,1990$ 
8) Itzkowitz SH, Yuan M, Montogomery CK, Kjeldsen T, Takahashi HK, Bigbee WL, Kim YS : Expression of Tn, sialosyl-Tn and T antigens in human colorectal cancer. Cancer, $49: 197-204,1989$.

9) Thor A, Ohuchi W, Szpak CA : Distribution of an oncological antigen tumor-associated glycoprotein-72, defined by monoclonal antibody B723. Cancer Res, $46: 3118-3124,1986$.

10) Nakasaki $H$, Mitomi $T$, Noto $T$, Ogoshi $K$, Hanaue $H$, Tanaka $Y$, Makuuchi $\mathrm{H}$, Clausen $\mathrm{H}$, Hakomori $\mathrm{S}$ : Mosaicism in the expression of tumor-associated carbohydrate antigens in human colonic and gastric cancers. Cancer Res, $49: 3662-3669,1989$.

11) Ryuko K, Iwanari O, Nakayama S, Kitao M, Karino K, Endo J : Basic evaluation of an immunoradiometric competitive inhibition assay for sialosyl Tn antigen in sera in women : Assay conditions and normal values. Cancer, $69: 2361-2367.1992$.

12) Ryuko K, Iwanari $O$, Nakayama $S$, Kitao $M$, Karino $K$, Endo J : Clinical evaluation of serum sialosyl-Tn antigen levels in comparison with CA125 levels in gynecologic cancers. Cancer, 69 : 2368-2378, 1992.

13) Motoo $Y$, Kawasaki H, Watanabe H, Satomura $Y$, Ohta H, Okai T, Sawatake $K$ : Serum sialyl Tn antigen levels in patients with digestive cancers. Oncology, $48: 321-326,1992$.
14) Yamaguchi A, Tukioka $Y$, Fushida S, Kurosaka $Y$, Kanno M, Yonemura $Y$, Miwa K, Miyazaki I : Serum sialyl Tn antigen in colorectal cancer and its relationship to prognosis. Jpn J Cancer Chemother, $19: 349-353,1992$.

15) Griffth J, , Reynolds S : Plasma sialyl transferase : Total and isoenzyme activity in the diagnosis of cancer of the colon. Clin Biochem, 15 : 46-48,1982.

16) Shimizu $S$ : Immunohistochemical examination of small gastric carcinomas and neighboring mucosa using monoclonal antibodies against Lewis blood group-related antigens and sialyl Tn antigen. Med J Kagoshima Univ, 41 : 63-80, 1989.

17) Japanese Research Society for Gastric cancer : General rules for the study of gastric cancer surgical and pathological. Jpn J Surg. 11 : 127-145, 1981.

18) Watanabe A, Nakatomi K, Sawada H, Yamada Y, Yano T, Nakano H : Clinical evaluation of serum sialyl Tn antigen in gastric cancer. Jpn J Gastroenterol Surg. 25: 1948-1952, 1992.

19) Ogata S, Maimonis PJ, Itzkowitz SH : Mucins bearing the cancerassociated sialosyl-Tn antigen mediate inhibition of natural killer cell cytotoxicity. Cancer Res, 52:4741-4746, 1992.
Offpnint requests to : K. Maeda, First Department of Surgery, Osaka City University Medical School, 1-5-7 Asahimachi Abeno-ku Osaka City, Osaka 545, Japan 
Rat model of bone metastasis obtained by mammary cancer transplantation

p 193 198

Akishige Ohta et al.

骨転移に対する放射線の照射効果を実験的に調べるため の動物モテルをつくることを目的として，近郊系のラット に発癌物質で発生させた乳癌細胞を骨䯣腔に移植し，形 態学的・X線学的検索を行い，骨転移ラットモテルの性 質について検討した。

[対象と方法] 乳癌(腺癌)は, 近郊系政性のFischer344系のラットに7,12-dimethylbenz (a) anthracene (DMBA) を释口投与して発生させた。この乳癌を同系のラット皮 下に移植して継代維持のできる移植性乳癌を得た。この 移植性乳癌細胞を同系ラットの骨䯣腔に注入して転移性 骨腫場の動物モデルを作成した。

本研究ては，乳癌細胞をラットの㮏の部位から大腿骨 の骨面膑に移植した時の動物の生存率の測定, X線写真 および組織病理学的検索を行った，また，乳癌細胞を移 植した大腿骨に对するX線照射の影瑤も調べた。

[結 果] 本実験て使用したラット移植性乳癌細胞 は，同系のラットの皮下あるいは骨㖪腔に移植すると， 移植したラットの全例に生着した。

100万個の乳湾細胞をラットの皮下および骨に移植し たときの生存日数は，それぞれ47士24日と21士11日であ った，乳癌細胞を移植された骨では，移植後約7日目頃 加線写真上に骨膜反応が認められた。

組織学的には移植後, 内膜および骨膜表面の休止期の 扁平な骨芽細胞層の近傍から多数の骨芽細胞と破骨細胞が 発生した．腫瑒組織の増大に伴って，既存骨およで新生骨 の両部位における破骨細胞による骨溶解と腫瘍細胞による 骨挰傷が進行して，最終的に骨析や骨破壊が起こって動物 は死に至る．乳癌細胞を骨に移植したラットでは，全例に 乳癌の肺への転移が起こった，一方，同様に皮下に移植し たラットで，乳癌の肺への転移は認められなかった，乳 癌細胞を移植した部位の骨をX線で照射するとラットの寿 命は延長した。

Radioimmunolocalization of human colorectal carcinoma xenografts with $F\left(a b^{\prime}\right)_{2}$ fragments of anti-sialyl Lewis a monoclonal antibody (MoAb) and a case report of radioimmunoscintigraphy with the radiolabelled fragment on recurrent rectal carcinoma patient

p 199 203

Junichi Sakamoto et al.

大腸癌培養細胞HT-29の細胞表面に発現しているシア ル化Lewis 抗原に対するモノクローナル抗体 (MoAB) H15を精製し，ペブシン，パパインにより $\mathrm{Fab}, \mathrm{F}\left(\mathrm{ab}^{\prime}\right)_{2}$ の fragment作成して, in vitro, in vivoの系において dosimetry analysisを行い, 腫場画像診断における有用性 を検討した。

[対象と方法] in vitroの系では，whole MoAbとFab， $\mathrm{F}\left(\mathrm{ab}^{\prime}\right)_{2}$ の抗原に対する親和性を大腸癌培養細胞株SW403 をターゲットとして, mixed hemmagglutination test (MHA)
にて判定した. in vivoの系では, whole MoAbと $\mathrm{F}\left(\mathrm{ab}^{\prime}\right)_{2}$ の 双方をクロラミンT法にで'2⿰氵より標識し、ヌードマウ ス腹腔内に投与し，その腫瘍 : 筋肉比, 腫場 : 肝比,お よび腫演：血液比を抗体投与直後より7日目まで連日測 定した。また，標識抗体投与後4日目には，移植大腸腫 偒，移植メラノーマ，血液，肝，正常大腸，および筋肉 における\% injected dose per gram (\%ID)の測定も行った.

ヌードマウスにおける腫瘍画像診断は， ${ }^{125}$ 標識抗体 (whole MoAbとF( $\left(\mathrm{ab}^{\prime}\right)_{2}$ fragment) 投与後連日シンチレーシ ヨンカメラを用いて，A-PおよびP-A画像の撮影を行っ た.

この結果をもとにして，直腸癌局所再発患者1例にお いて ${ }^{131}$ 標識 $F\left(a b^{\prime}\right)_{2}$ 抗体を投与し，ガンマカメラを用いて 抗体の局在を検討した．抗体投与による重篤な副作用は 認められなかった。

[結 果] ヨード標識をしたwhole MoAbと Fab, $\mathrm{F}\left(\mathrm{ab}{ }^{\prime}\right)_{2}$ の大腸癌細胞株SW403に対するMHAテストでは whole MoAbが $\times 10^{4}, \mathrm{Fab}$ が $\left.\times 10, \mathrm{~F}\left(\mathrm{ab}^{\prime}\right)_{2}\right)^{2} 5 \times 10^{3}$ の希釈 まで反応を示した.この結果，H-15MoAbに関しては, 放射性ヨード標識後はFab fragmentの抗原結合能がいち じるしく低下することが明らかになった。

in vivoの系においては，標識抗体投与後4７日目にお いて腫堭：筋肉比がwhole MoAbで×5, F $\left(\mathrm{ab}^{\prime}\right)_{2}$ では $\times 75$ であり, 腫瘍：肝比は, whole MoAbで×3，F(ab') 25, 腫瘍：血液比はwhole MoAbで ×1.5〜1.8であるのに 对し, $\mathrm{F}\left(\mathrm{ab}^{\prime}\right)_{2}$ で $\times 10$ と $\mathrm{F}\left(\mathrm{ab}^{\prime}\right)_{2}$ fragmentのより高い腫瘍 特異的集積が明らかになった。 また，\%IDも F(ab') は は移 植大腸腫笣 0.56 (whole MoAbでは0.36), 移植メラノーマ $0.03(0.08)$, 血液0.09 (0.25), 肝0.07 (0.10), 正常大腸 0.05 $(0.09)$, 筋肉0.02 (0.06) と移植大腸腫墽部において高値 を示していた。ヌードマウスにおける画像診断ては， $\left.\mathrm{F}(\mathrm{ab})_{2}\right)_{2}$ 抗体投与後36時間で, 移植大腸腫瘍部に抗体の集 皘がみられ, whole MoAbに比し，早期に腫瘍画像を得 ることができた。また，直腸癌局所再発症例において $\mathrm{F}\left(\mathrm{ab}^{\prime}\right)_{2}$ を投与した1例では，投与後3日目において腫瘍画 像が抽出され，臨床応用への有用性が示唆された。

[考察] wholeのMoAbに对 LF $\left(\mathrm{ab}^{\prime}\right)_{2}$ fragment 腫瘍 画像診断に用いることは，(1) 早いclearance，(2) 抗体の 腫湯へのaccess, (3) Fckよる非特異的集積の隇少などの 利点があるといわれている。

今回の検討により，in vivo，in vitro，また臨床の場に おいても $\mathrm{F}\left(\mathrm{ab}^{\prime}\right)_{2}$ fragmentの高度な腫笉特異的集積が証明 され，今後の臨床応用への有用性が示されたものと考之 られる。

Prognostic value of sialyl-Tn antigen in gastric carcinoma

p 205 208

Kiyoshi Maeda ot al.

近年，糖鎖抗原は腫瘍マーカーとして重要な位置を占 めている．糖鎖性腫煬マーカーの一つであるcarbohydrate antigen 19-9 (CA19-9), sialyl Lewis ${ }^{x}-\mathrm{i}$ (SLX) などは基幹桾 鎖を抗原としたものであるが，これに対しシアリル Tn 
抗原 (sialyl Tn antigen, STN) はモノクローナル抗体TKH2 が認識する糖鎖抗原であり，母核糖鎖に属する．近年， STN抗原の癌関連抗原としての意義が認識され，各種癌 において新しい腫湯マーカーとして注目されている。

今回，筆者らは術後再発および再発形式と原発巣にお けろSTN抗原の発現との関係について免疫組織化学的に 検討した.

[対象と方法] 1986，87年に当院に入院した胃癌患者 のうち，治瘾切除された152例を対象とした。

これらの症例の切除標本を $10 \%$ ホルマリン固定の後, バラフィン包埋し4 $\mu \mathrm{m}$ 切片を作成した。一次抗体とし てTKH2 (Otsuka Assay Lab.) を20倍希釈して用い, 室温 にて組織切片と1時間反応させた. streptoavidine-biotin法 にて免疫組織化学染色を行い, 発色はdiaminobenzidine を用いた。判定は切片を光影的に観察し，癌組織中の陽 性範囲が5\%以上のものを陽性とした。

有意差検定はX検定を用いた。

[結 果] STN抗原は胃癌組織，特に細胞質，細胞膜 において強い発現を認めた。胃原発巣におけるSTNの発 現は74例 (48.7\%)にみられた。

臨床病理学的諸因子別にSTNの発現を検討した。リン パ節転移陽性症例ではンンパ節転移陰性の症例にくらべ て有意に（P<0.01）STNの発現率は高かった。また，壁深 達度，組織学的進行度が進むにつれ，STN発現率は高值 を示した。

STNの発現と予後との関係については, STN発現陽性 例では有意に $(P<0.01)$ 予後不良であった.

[結 論] 胃癌組織中のSTN抗原の発現は組織学進行 度と相関し，STN抗原発現例ては発現陰性例にくらべ, 有意に予後不良であった. STN抗原の免疫組織化学的検 討は予後の指標の一つとして，また術後の補助療法の選 択において有用であると思われた。

Changes in estrogen and progesterone receptor levels before and after preoperative treatments in primary advanced breast cancers p 209 212

Yuichi lino, Noritaka Sugamata et al.

原発進行乳癌24例において術前治療前後のエストロ ゲンレセブターおよびブロゲステロンレセブターが dextran-coated charcoal法で測定された。 エストロゲンレ セブターレベルの平均値は, 術前治療後有意に低下

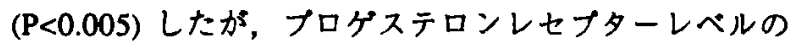
平均值は有意には変動しなかった，すべての症例におい てエストロゲンレセブターもブロゲステロンレセブター も陰性から陽性へとは変動しなかった。治療前における レストロゲンレセプターの平均值は有効例のほうが無効 例よりも高かった。レストロゲンレセブターレベルの平 均値は, 有効群では有意に低下 $(\mathrm{P}<0.03)$ したが, 無効群 では有意には変動しなかった。

これらの結果は，ホルモンレセブターに関しては定性 よりも定量的値のほうが臨床的により有用であることを 示している，ヒト乳癌のエストロダンレセブターレベル
は通常，治療後に低下するかまたは変動しないかのどち らかであり，陰性から陽性に変動することはないと思わ れる.

\section{Systemic induction chemotherapy in multidisciplinary treatment for locally advanced breast cancer \\ p 213 216}

Yuichi lino, Noritaka Sugamata et al.

21人の局所進行乳癌患者を対象にアンスラサイクリン 系抗癌剂を用いた術前化学療法が行われた。奏効率は術 前ホルモン療法や術前照射を行った 18 人のhistorical control群の乳癌患者よりも高かった (48\%対 $28 \%, P<1.0)$. 導入化学㙩法後に定型的乳房切除術や搪大乳房切除術が

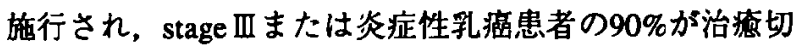
除であった。両群間の生存曲線に有意差はなかったが, 術前化学療法群の $50 \%$ 生存期間はコントロール群のそれ よりもながかった (118力月対23力月). 術前の化学療法 片としてアンスラサイクリン系抗癌郕であるアドリアマ イシン, エビルビシン, THP-アドリアマイシンが, そ れぞれ単剂または他剤との併用で用いられた。副作用は 耐えうるものであった。

アンスラサイクリン系抗癌郕を用いた全身性化学療法 は，集学的治療の一環として局所進行乳癌に有効である。

\section{Chemosensitivity test of advanced lung cancers using the chick embryo assay \\ p 217 222}

Motohiro Tanaka et al.

肺癌に対する術後多剂併用化学療法の有用性を検討す

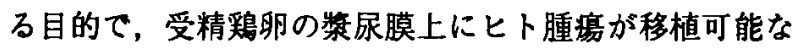
実験系 (鶏卵法) を抗癌剂感受性試験として応用し, 臨 床効果との比較を行った。

[対象と方法]本施設に括いて手術を施行された原 発性肺癌117症例に対し，その切除材料を用いて抗癌剂 感受性試験を行った。内訳は男91例，女26例て，年齢は 平均64.3葴，組織型別ては腺癌51例，扁平上皮癌46例， 腺扁平上皮癌8例，大細胞癌5例，小細胞癌7例であった。

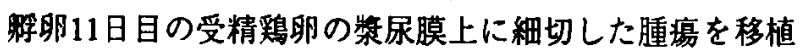
し，3日後に抗癌剤を槳尿膜の血管内に投与した。腫瘍 移植の7日後に生育した腫瘍塊を摘出して抗腫湯効果を 判定した，抗癌郕は，臨床投与量を胎思の平均体重に換 算して投与した。現在，肺癌に対して頻用されている CDDP + VDS (PV療法), CDDP + ADM + MMC (PAM療 法), MMC+VDS + CDDP (MVP療法) の三つの多剂併用 化学潦法について鵎卵法と臨床効果との比較検討を行っ た. 感受性試験を行った117症例のうち, 臨床効果との 相関性が検討可能な症例は26例であった。

臨床効果は，術後のfollow upを参考にし，N期または 絶対非治瘾切除例では 1 年, それ以外の回期では 2 年, I 期では 3 年以上生存した場合その化学療法を“有効”と 判定した.

[結 果] 鹞卵法を用いて感受性試験を行った117症 例に対する各化学療法の有効率は，PV療法が16.9\%, 